\title{
Performance and carcass characteristics of lambs fed on diets supplemented with glycerin from biodiesel production
}

\section{Marco Antonio Bensimon Gomes ${ }^{1}$, Gentil Vanini de Moraes $^{2}$, Marcela Mataveli ${ }^{3}$, Francisco de Assis Fonseca de Macedo ${ }^{2}$, Thais Cristina Carneiro ${ }^{1}$, Robson Marcelo Rossi ${ }^{4}$}

\author{
1 Programa de Pós-graduação em Zootecnia - Universidade Estadual de Maringá, 87020-900, Maringá, PR \\ 2 Departamento de Zootecnia - Universidade Estadual de Maringá. \\ ${ }^{3}$ Embrapa CPAFAC - Rio Branco, AC \\ ${ }^{4}$ Departamento de Estatística - Universidade Estadual de Maringá.
}

\begin{abstract}
This study was carried out to evaluate the influence of diets supplemented with glycerin as an alternative ingredient to corn on the performance and carcass characteristics of Santa Inês confined lambs. The study involved 27 lambs aged 90 days, having an average initial weight of $26.33 \pm 0.15 \mathrm{~kg}$. Lambs were randomly distributed into a control group and groups with diets containing 15 and $30 \%$ glycerin in the total feed. Diet was formulated with $40 \%$ roughage and $60 \%$ concentrate. The experimental design was completely randomized, and the production performance and carcass characteristics were analyzed by analysis of variance, and the subjective carcass characteristics, by general linear models. The daily average gain was $0.21,0.24$ and $0.23 \mathrm{~kg}$ /day; feeding conversion was $6.39,5.73$ and $5.92 \mathrm{~kg}$ of diet $/ \mathrm{kg} \mathrm{BW}$ for control animals, and those fed with 15 or $30 \%$ glycerin, respectively, without treatment differences. Lambs were slaughtered, weighing 34 to $36 \mathrm{~kg}$, and average weight of the cold carcass and commercial carcass yield were evaluated. The results were, respectively, $15.97 \mathrm{~kg}$ and $49.18 \%$, for control, $15.96 \mathrm{~kg}$ and $48.31 \%$ for animals fed with $15 \%$ glycerin, and $15.79 \mathrm{~kg}$ and $47.87 \%$ for those treated with $30 \%$ glycerin, with no treatment effects. Meat tenderness and cooking loss averages were not affected by diets, with $5.07 \mathrm{~kg}$ and $40.45 \%, 5.10 \mathrm{~kg}$ and $40.81 \%$, and $5.27 \mathrm{~kg}$ and $39.04 \%$, respectively, for control, and those fed with 15 or $30 \%$ glycerin. Therefore, it is possible to conclude that up to $30 \%$ of medium purity glycerin in the dry matter of the diet can be used to replace corn, without any negative effect on lamb performance or carcass characteristics.
\end{abstract}

Key Words: dressing percentage, feed conversion, glycerol, meat quality, weight gain

\section{Introduction}

Meat production of feedlot lambs decreases production cycles and improves product quality, generating bigger income for sheep owners (Siqueira et al., 2001).

Alternative nutrients such as corn are important in the composition of feeds, since they help decrease production costs (Donkin \& Doane, 2007). These authors have also observed that glycerin, due to its energetic properties, sweet flavor and widespread availability in the Biodiesel industry, is a promising element in animal feeding that could, in part, substitute energetic concentrates present in the diet, mainly, corn.

According to Neilsen \& Ingvartsen (2004), glycerol can be absorbed by the rumen or the small intestine, and is the precursor of glucose in the liver's gluconeogenic pathways. Kristensen \& Raun (2007) measured the absorption of glycerin and the metabolism of glycerol in cattle liver, administering through a ruminal cannula, $925 \mathrm{~g} /$ day of glycerin, having $85 \%$ glycerol. These authors also recovered, in the portal vein, $10 \%$ of the administered glycerol, absorbed by the liver and converted into glucose. The glycerol not recovered in the portal vein was, presumably, converted into propionate in the rumen, contributing to the gluconeogenesis.

Bines \& Hart (1984) revealed that higher concentrations of propionate increase blood levels of insulin, facilitating protein and fat synthesis, and decreasing lipolysis. Lebzien $\&$ Aulrich (1993), in a digestibility assay performed in dairy cows, reported that glycerol contains $9.5 \mathrm{MJ} \mathrm{EL}_{1} / \mathrm{kg}$ of lactation's liquid energy. Therefore, considering it is necessary for sheep owners to produce good-quality meat at a competitive price (Lage et al., 2010), glycerin, a byproduct from biodiesel, has an attractive price when compared with corn, aligned with an ever-growing world production, which transforms it into a promising alternative (Abo El-Nor et al., 2010). This study was carried out to evaluate the influence of lambs fed on diets supplemented with glycerin of medium purity on carcass characteristics, including 15 to $30 \%$ of the total diet substituting corn. 


\section{Material and Methods}

This experiment was carried out in agreement with the ethical principles for animal research approved by the Comitê de Conduta Ética no uso de Animais em Experimentações (Animal Research Ethics Committee) from the Universidade Estadual de Maringá (UEM).

The experiment was performed at the setor de ovinocultura of Fazenda Experimental at the Universidade Estadual de Maringá (UEM), Paraná. Chemical analyses were undertaken in the Laboratório de Nutrição Animal (LANA), Departamento de Zootecnia at UEM, Complexo de Centrais de Apoio à Pesquisa at UEM (CONCAP), and at Instituto de Tecnologia do Paraná (TECPAR), Divisão de Biocombustíveis, Curitiba, Paraná.

For this experiment, twenty-seven weaned Santa Inês lambs with average age of 90 days and average weight of $26.33 \pm 0.15 \mathrm{~kg}$ were used. The animals were kept in a sheltered hangar, with a suspended, slatted floor, randomly distributed in individual pens, forming the control group (no glycerin, $\mathrm{n}=7)$, the $15 \%$ glycerin group $(\mathrm{n}=10)$ and the $30 \%$ glycerin group $(n=10)$. Lambs were dewormed before the beginning of the experiment with $1 \mathrm{~mL}$ s.c. $1 \%$ Moxidectin(Fort Dodge).

Blood samples $(10 \mathrm{~mL})$ from the jugular vein were collected, in a recipient containing an antiglycolytic agent (sodium fluoride) and anticoagulant (heparin), to determine glucose and insulin at the beginning and on days 20, 40 and 60 of the experiment, centrifuged at 1,500 g, in an Excelsa centrifuge 206-BL-Fanem model, for 20 minutes. After blood sampling and immediate centrifugation, $1 \mathrm{~mL}$ was collected from the plasma of each animal from each treatment, to constitute one pool sample for glucose and insulin analyses. Both glucose and insulin, after the plasma had been previously homogenized, were divided in two equal parts of $1.5 \mathrm{~mL}$ and stored at a temperature of $-20^{\circ} \mathrm{C}$ in cryogenic tubes until the very moment of the analyses. Insulin was measured by chemiluminescence, on an Immulite DPCMedlab apparatus. Glucose was determined by an enzymatic/colored method, using Cobas Mira Plus $\mathrm{CC}^{\circledR}$ (ROCHE) equipment.

Glycerin was acquired from a soybean oil-based biodiesel supplied and analyzed by Instituto de Tecnologia do Paraná (TECPAR) Biofuels Division, in Curitiba, Paraná. The chemical composition of medium purity glycerin was $83.15 \%$ glycerol, $6 \%$ water, $120 \mathrm{ppm}$ methanol, $1.3 \%$ sodium, $7.4 \%$ ash, $0.12 \%$ crude protein, $3,628 \mathrm{kcal} / \mathrm{kg}$ gross energy, $0.0691 \%$ calcium, and $0.0053 \%$ phosphorus. To calculate the formulated diets, the group took $15.8 \mathrm{KJ} / \mathrm{kg}$ of glycerin (Thompson \& He, 2006), sourced from the biodiesel production using soybean oil.
At the beginning of the experiment, animals were weighed and submitted to each groups' correspondent feed (control, $15 \%$ glycerin or $30 \%$ glycerin), based on the intake of $3 \%$ of the liveweight; 5 days later, $4 \%$ of the liveweight; and on the $8^{\text {th }}$ day, the experiment began, with a 5\% supply of liveweight once a day. To evaluated lambs' daily intake, leftovers were weighed and subtracted from the amount supplied the day before, to obtain the daily average intake. The weekly weighing was performed with the animals in a fasting state, to adjust the stipulated intake at $5 \%$ of individual liveweight. The concentrates were balanced with and without glycerin (Table 1) and oat hay was used as forage (Avena strigosa Schreb), in the proportion of $60 \%$ concentrate and $40 \%$ roughage.

The feed was formulated according to the NRC (2007), for a $0.200 \mathrm{~kg}$ /daily weight gain and the levels of nutrients in feeds were determined according to methodologies described by Silva \& Queiroz (2002).

Concentrate was previously mixed without glycerin, in a double paddle batch mixer, having a $500 \mathrm{~kg}$ capacity, model M1 - Máquinas Pereira - Londrina, PR. The oat hay was ground in a MM2 model mixer, Máquinas Pereira Londrina, PR, without a sieve.

Animals were slaughtered upon reaching between 34 and $36 \mathrm{~kg}$ of BW, after a solid fasting of 18 hours, when they received only water. Animals were weighed to determine the BW before the slaughter, then slaughtered.

Table 1 - Percentage and chemical composition of feed ingredients $(\% \mathrm{DM})$

\begin{tabular}{|c|c|c|c|}
\hline \multirow[b]{2}{*}{ Items } & \multicolumn{3}{|c|}{$\begin{array}{l}\text { Levels of glycerin in } \\
\text { total diet }(\%)\end{array}$} \\
\hline & 0 & 15 & 30 \\
\hline \multicolumn{4}{|l|}{ Ingredients } \\
\hline Ground corn & 37.89 & 19.24 & 0.59 \\
\hline Soybean meal & 20.41 & 24.06 & 27.71 \\
\hline Glycerin & 0 & 15 & 30 \\
\hline Premix mineral ${ }^{1}$ & 1 & 1 & 1 \\
\hline Common salt & 0.5 & 0.5 & 0.5 \\
\hline Sodium bicarbonate & 0.2 & 0.2 & 0.2 \\
\hline Oat hay (Avena strigosa Schreb) & 40 & 40 & 40 \\
\hline \multicolumn{4}{|l|}{ Chemical composition } \\
\hline Dry matter & 95.988 & 94.720 & 93.492 \\
\hline Crude protein & 17.04 & 17.16 & 16.92 \\
\hline Total digestible nutrients & 73.13 & 72.43 & 71.56 \\
\hline Ethereal extract & 2.26 & 1.77 & 1.03 \\
\hline Neutral detergent fiber & 9.65 & 9.72 & 10.13 \\
\hline Acid detergent fiber & 22.71 & 21.40 & 18.56 \\
\hline Calcium & 0.26 & 0.31 & 0.22 \\
\hline Phosphorous & 0.22 & 0.28 & 0.20 \\
\hline
\end{tabular}

R. Bras. Zootec., v.40, n.10, p.2211-2219, 2011 
Animals were stunned with an electric shock of $220 \mathrm{~V}$ and 600 watts for 8 seconds; then, jugular and carotid arteries were cut, causing exsanguination; finally, skinning was performed.

Skin, blood, reproductive system with the bladder, kidneys with perirenal fat, spleen, liver, heart, trachea and lungs, empty gastrointestinal tract, gastrointestinal content, head and hooves were collected and weighed for slaughter BW percentage. After evisceration, carcasses were weighed to obtain the hot carcass weight and sent to $4{ }^{\circ} \mathrm{C}$ freezers for 24 hours. After this 24 hour period, the cold carcass weight was calculated. The cooling loss and the commercial carcass yield were calculated using the ratio between the cold carcass weight and the slaughter live weight. Biological carcass yield was obtained by the ratio between the hot carcass weight and the empty body weight, where empty body weight was the slaughter live weight minus gastrointestinal contents. Weight loss between farm and slaughter was calculated by the percentage difference between liveweight losses obtained 18 hours before the fasting of solids and the slaughter live weight (Macedo et al., 2006).

Evaluations of carcass conformation and fat cover score (1.0 to 5.0 points), fat color, fat consistency and meat color (1.0 to 3.0 points) were noted, where the variation of 0.5 points was considered subjective (Osório, 2002), and evaluated by three people. To determine carcass compactness index, in $\mathrm{kg} / \mathrm{cm}$, cold carcass weight was divided by the internal length of carcass, obtained by the maximum distance between the pubis-ischium symphysis and the first rib, at its medium point, measured with a metallic measuring tape. Leg compactness index was obtained by back width, measured by a compass having metallic ends, divided by the length of the leg, which is the distance between the perineum to the higher edge of the articular surface of the tarsal-metatarsal complex, measured with a metallic measuring tape (Macedo et al., 2000). Subsequently, carcasses were sectioned half way and each left half was weighed and subdivided into seven anatomic regions, each weighed individually (Reis et al., 2001). Sections were classified according to the anatomic regions: prime cuts, which comprise leg and loin; choice cuts, shoulder and rack; and finally, good cuts, formed by trimmed rib, breast and rib points and neck.

Through a transversal cut between the $12^{\text {th }}$ and $13^{\text {th }}$ ribs, the muscle Longissimus dorsi could be observed, which was outlined with the aid of a transparency. Next, loin eye area $\left(\mathrm{cm}^{2}\right)$ was calculated with the computer software Spring Instituto de Pesquisas Espaciais (Spacial
Research Institute, INPE), Copyright 1991-2007, with a graphics tablet.

With the help of a caliper rule, the Longissimus dorsi muscle, its longer and shorter lengths, and larger and smaller fat thickness were measured. Two sub-samples were collected from the Longissimus dorsi, along with the fat cover, which were identified and stored at $-18{ }^{\circ} \mathrm{C}$ until the beginning of the analyses. For the analyses, samples were defrosted for 12 hours in a domestic refrigerator between 4 and $8^{\circ} \mathrm{C}$. Loin was then dissected - bones and fat depth were removed. Part of the sample was sent to testing for cooking losses and shear force (Wheeler et al., 2007), and the remainder was grated in a food processor and homogenized to determine humidity (\%), total fat (\%), ash (\%) and crude protein (\%). Analyses of duplicate Longissimus dorsi samples were performed according to procedures described by Silva \& Queiroz (2002).

To determine cooking losses and shear force, samples were defrosted at room temperature until their internal temperature reached 2 to $5^{\circ} \mathrm{C}$ (Wheeler et al., 2007). Samples were then weighed and wrapped in aluminum foil and cooked on a grill at a temperature between 149 and $163^{\circ} \mathrm{C}$. Samples were turned over and cooked for 5 minutes on both sides until they reached an internal temperature of $71^{\circ} \mathrm{C}$, ascertained by a digital stick thermometer. When reaching $71^{\circ} \mathrm{C}$, samples were left to sit for 2 minutes, dried using kitchen towel and weighed to determine cooking losses. After weighing, samples were trimmed, and thin sections from the lateral and extremities were removed; 4 samples, parallel to the muscle fibers and having $1 \mathrm{~cm}$ of thickness and $5 \mathrm{~cm}$ of length were obtained, to measure the shear force in a texture analyzer (TA.XTPlus - Texture Analyser, with a Warner-Bratzler Blade probe, Texture Expert Exponent - Stable Micro Systems software, Ltd in Godalming, Surrey, UK. SMS). For each sample, 6 shear force results were obtained.

The experimental design was completely randomized. Dry matter intake, average daily matter intake during the experiment, feed conversion, average daily gain, initial weight and slaughter weight, carcass yield and anatomic cuts were evaluated by variance analysis, transforming, if necessary, data to the logarithmic notation, arc/sine or square root and applying Tukey's test at $5 \%$. The adjusted statistical model was:

$$
Y_{i j}=\mu+T R A T_{i j}+\left(P I_{i j}-\overline{P I}\right)+e_{i j},
$$

in which: $Y_{i j}=$ Response of animal $\mathrm{i}$ for treatment $\mathrm{j}$; TRAT $_{i}=$ Treatment with levels $0 \%, 15 \%$ and $30 \%$ of ration glycerin; $P I_{i j}-\overline{P I}=$ Initial weight corrected by mean; $e_{i j}=$ error. 
Quantitative carcass data were analyzed by general linear models (GLM) of SAS (2001), at 5\%, assuming a gamma distribution for responses, with a canonical bond function (dispersion parameter $\phi^{-1}$ ). For carcass conformation, i.e., fat depth, fat color, fat consistency and meat color, the adopted model was:

$Y_{i j} \sim G\left(\mu_{i}, \phi\right)$

$\mu_{i}^{-1}=\mu+\beta_{2} T R A T_{15 \%}+\beta_{3} T R A T_{30 \%}+\beta_{4}\left(P I-\overline{P I}_{i}\right)$,

in which $1=0$.

The differences were identified by parametric tests at $5 \%$.

\section{Results and Discussion}

Due to the viscous aspect of glycerin, whose density is $1.260 \mathrm{~g} / \mathrm{mL}$ (IUPAC, 1997), the feeds containing 15 and $30 \%$ glycerin, once processed, presented a humidified texture with an oily appearance. Twelve hours after the mixture, due to glycerin's hygroscopicity, it was absorbed by all ingredients included in the feed. The glycerin used in this experiment was sweet and mildly salty, and this characteristic appears to have conferred a pleasant flavor and aroma to the final mixture leading to a great acceptation by the lambs. In the inspection performed during slaughter, and in visual examination of the liver, no color, size or lesion alterations were observed, which is in accordance with Kijora et al. (1995), where there was no hepatic alteration in swine fed on feed containing up to $10 \%$ glycerin.

Average serum glucose levels for the control group were, respectively, $79.00 ; 76.50 ; 74.50$ and $66.00 \mathrm{mg} / \mathrm{dL}$ and insulin $1.25 ; 4.05 ; 4.75$ and $1.90 \mu \mathrm{UI} / \mathrm{mL}$, where gradual glucose and insulin variation was observed. Glucose results for the animals in the $15 \%$ glycerin group were $71.50 ; 74.00$; 79.50 and $76.00 \mathrm{mg} / \mathrm{dL}$ and insulin, 3.70; 3.70; 4.25 and $4.90 \mu \mathrm{UI} / \mathrm{mL}$. A numeric increase in glucose and insulin blood levels was observed. In the group fed with $30 \%$ glycerin, the average glucose and insulin results were, respectively, $69.5 ; 84.00 ; 73.00$ and $70.00 \mathrm{mg} / \mathrm{dL}$ and 0.25 ; $6.50 ; 3.75$; and $3.30 \mu \mathrm{UI} / \mathrm{mL}$, results similar to those observed by Pethick et al. (2000), that reported a mixture of 3.5\% glycerol and $1.5 \%$ propylene glycol caused hyperglycemia in sheep, increasing the plasmatic insulin.

When observing the blood levels of glucose and insulin of animals fed with $15 \%$ or $30 \%$ glycerin, it was possible to assume that the numeric increase observed in the glucose and insulin concentrations may have been caused by a major production of ruminal propionic acid, originated from the glycerin's fermentation, also observed by Bines \&Hart (1984). Study results suggest that feeds containing glycerin were more efficient in stimulating the secretion of insulin in sheep, facilitating the restitution of muscular glycogen (Pethick et al., 2000).

Data referring to lamb performance (Table 2), were not influenced by glycerin $(\mathrm{P}>0.05)$. The confinement period varied by animal as each reached weights of between 34 and $36 \mathrm{~kg}$, and were then slaughtered, but no variations relating to the feedlot period were observed $(\mathrm{P}>0.05)$ (Table 2), which differs from Gunn et al. (2010a), who reported that sheep fed on $30 \%$ or more glycerin needed more time to reach the desired slaughter weight, which is justified by the decrease in DM ingestion.

The results concerned with average daily gain, DM ingestion in relation to $\mathrm{BW}$ and average $\mathrm{DM}$ intake (Table 2) agree with the predicted averages of the NRC (2007): $0.200 \mathrm{~kg}$ average daily gain, 3.99\% DMI of the BW and $1.2 \mathrm{~kg}$ average daily DM intake for this category of animal.

The average daily intake of DM observed in this study was superior to that reported by Gunn et al. (2010a) in confined wethers and ewes, presenting an average daily intake of: $1.13 ; 1.19 ; 1.0$ and $0.90 \mathrm{~kg}$ per animal per day with, respectively, $0,15,30$ and $45 \%$ glycerin per kg in their total feed.

Dry matter ingestion results, though undertaken with bovine, in feeds containing high levels of grains, indicated no influence on DM ingestion when administering up to $16 \%$ glycerin in the total feed (Defrain et al., 2004; Chung et al., 2007; Mach et al., 2008). On the other hand, Schröder \& Südekum (2007), Pyatt et al. (2007) and Parsons et al. (2009), working with feedlot bovines, observed a reduction on DM ingestion when the levels of glycerin were higher than $10 \%$, equal to that observed by Lage et al. (2010), in lambs with more than $10 \%$ glycerin. The reduction of the acetate:propionate relation can also explain the decrease in intake as observed by Abo El-Nor et al. (2010). Moreover,

Table 2 - Performance of Santa Inês lambs confined and fed rations with or without glycerin

\begin{tabular}{lcccr}
\hline Variables & \multicolumn{3}{c}{ Glycerin level (\%) } & CV \\
\cline { 2 - 4 } & 0 & 15 & 30 & $(\%)$ \\
\hline Initial average weight (kg) & 26.07 & 26.19 & 26.49 & 10.81 \\
Final average weight (kg) & 34.57 & 35.65 & 35.82 & 4.92 \\
Confinement period (days) & 43.61 & 42.95 & 46.72 & 25.13 \\
Weight gain during period (kg) & 8.38 & 9.41 & 9.47 & 14.83 \\
Average daily gain (kg) & 0.21 & 0.24 & 0.23 & 26.26 \\
DM ingestion (BW \%) & 4.30 & 4.43 & 4.36 & 8.10 \\
Average DM intake (kg) & 53.06 & 53.34 & 56.60 & 20.63 \\
Average daily intake of DM (kg) & 1.26 & 1.30 & 1.27 & 7.75 \\
Feed conversion & 6.39 & 5.73 & 5.92 & 23.50 \\
\hline
\end{tabular}

Treatment means had no statistically significant difference (Turkey's test $\mathrm{P}>0.05$ ). DM - Dry matter; CV - Coefficient of variation. 
the fact that this study indicates no dietary influence on ingestion parameters or carcass characteristics, could have been due to the differences in the ingredients composing the diet and the purity level of the glycerin, when compared with those used on studies having determined negative results - these are factors that can justify such divergence of results.

There was no dietary effect $(\mathrm{P}>0.05)$ on feed conversion, nor on average daily gain (Table 2). Gunn et al. (2010a; $2010 \mathrm{~b}$ ) recognized that upon increasing glycerin in the diet, feed conversion was improved, although the daily weight gain decreased. Parsons et al. (2009), when studying confined heifers, ascertained an improvement on the feed conversion efficiency when adding up to $12 \%$ glycerin to the diet, yet additions of more than $16 \%$ glycerin had the opposite effect, decreasing the feed conversion efficiency. Pyatt et al. (2007), when working with Angus bovines, observed an improvement on feed conversion, when $10 \%$ of corn was substituted by crude glycerin.

Average daily gain was not influenced by glycerin levels ( $P>0.05$; Table 2). This result goes against those by Pyatt et al. (2007), who observed an improvement on the average daily gain of bovines, and with Gunn et al. (2010a, 2010b), who, when studying sheep, observed a decrease on weight gain from the moment glycerin was $30 \%$ of the total diet.

Variations $(\mathrm{P}<0.05)$ amongst feeds were found in carcass yield analyses (Table 3). Gunn et al. (2010a), when studying lambs slaughtered at $55 \mathrm{~kg}$, did not observe any effect from zero to $45 \%$ of glycerin on carcass weight, in agreement with the results observed in this study. The cooling loss (CL) means of $0.72 ; 0.80$; and $0.58 \%$ in feeds with and without glycerin (Table 3 ) were low, when compared with those obtained by Macedo et al. (2006), who observed that confined Corriedale, crossbred Bergamácia $\times$ Corriedale and crossbred Hampshire $\times$ Corriedale lambs had an average of $3.35 \% \mathrm{CL}$, which could indicate that diets with glycerin did not influence the CL, since they did not differ from control groups.

No effect $(\mathrm{P}>0.05)$ of glycerin on commercial carcass yield was observed. However, biological carcass yield of control groups and $15 \%$ glycerin were superior $(\mathrm{P}<0.05)$ to that of lambs treated with $30 \%$ glycerin.

Garcia et al. (2000), when studying pure and crossbred Santa Inês lambs, recognized commercial carcass yield results averaging $53.4 \%$, of finishing Santa Inês feedlot lambs, superior to the means found in this study. However, the biological carcass yield was found to be inferior (53.1\%) to those of the present study (54.15 to $56.90 \%$ ).

No effect of glycerin $(\mathrm{P}>0.05)$ was observed on the carcass compactness index, which agrees with the results
Table 3 - Carcass characteristics of confined Santa Inês lambs fed rations with or without glycerin

\begin{tabular}{lcccr}
\hline Variable & \multicolumn{3}{c}{ Glycerin level (\%) } & \multirow{2}{*}{\begin{tabular}{c} 
CV \\
\cline { 2 - 4 }
\end{tabular}} \\
\cline { 2 - 4 } & 0 & 15 & 30 & \\
\hline Hot carcass weight (kg) & 16.09 & 16.08 & 15.88 & 4.38 \\
Cold carcass weight (kg) & 15.97 & 15.96 & 15.79 & 4.48 \\
Weight loss between farm and & 5.21 & 6.87 & 7.62 & 36.77 \\
slaughter (kg)* & & & & \\
Cooling loss (\%)** & 0.72 & 0.80 & 0.58 & 63.58 \\
Commercial carcass yield (\%) & 49.18 & 48.31 & 47.87 & 2.78 \\
Biological carcass yield (\%) & $56.90 \mathrm{a}$ & $55.89 \mathrm{ab}$ & $54.15 \mathrm{~b}$ & 3.44 \\
Carcass compactness index & 0.242 & 0.250 & 0.239 & 8.17 \\
(kg/cm) & & & & \\
Leg compactness index & 0.453 & 0.492 & 0.450 & 12.22 \\
\hline
\end{tabular}

a,b Means followed by different letters are statistically different (Turkey's test $\mathrm{P}<0.05)$. CV - Coefficient of variation.

* Weight loss between farm and slaughter was transformed into a logarithm for analysis.

** Cooling loss was analyzed based on the square root.

of Musselman et al. (2008), from crossbred sheep with 0 to $45 \%$ glycerin in the diet. When analyzing the results found by these authors and comparing them the carcass compactness index of the study's control group, it can be determined that diets containing 15 or $30 \%$ glycerin were efficient, demonstrating how glycerin can be a viable alternative for diets of feedlot lambs.

Diets did not influence $(\mathrm{P}>0.05)$ leg compactness index, and average values were superior to the 0.30 leg compactness index found by Yamamoto et al. (2005).

Musselman et al. (2008), working with 24 lambs, 24 ewes and 24 crossbred (Southdown $\times$ Suffolk) wethers, fed diets containing $0,15,30$ and $45 \%$ crude glycerin of the total diet, reported similar commercial carcass yield results to those of this study, with 0 and $15 \%$ glycerin and a yield reduction for higher levels of glycerin. In this study, biological carcass yield decreased from the moment glycerin reached $15 \%$ of the total diet (Table 3). Mach et al. (2008) and Parsons et al. (2009), in addition to studies conducted by Gunn et al. (2010b) with lambs, working with finishing bovines, did not find any influence of glycerin level on carcass characteristics. The subjective carcass evaluation was performed according to Osório (2002).

There was no dietary effect $(\mathrm{P}>0.05)$ concerning control or glycerin groups (Table 4 ) on carcass conformation, fat score, fat color, fat consistency and meat color. However, it could be observed that animals fed with $30 \%$ glycerin had a lower fat cover score, whereas animals fed with $15 \%$ glycerin had a lower score for meat color $(\mathrm{P}<0.06)$.

The fat cover score can be classified as scarce, but with a higher value $(\mathrm{P}<0.06)$ found on animals fed with a diet containing $15 \%$ glycerin, when compared with the control and $30 \%$ glycerin group. The results found for the $15 \%$ glycerin group could be related to the changes in 
Table 4 - Subjective carcass evaluation of confined Santa Inês lambs fed rations with or without glycerin

\begin{tabular}{|c|c|c|c|c|c|}
\hline \multirow[t]{2}{*}{ Variable } & \multicolumn{3}{|c|}{ Glycerin level (\%) } & \multirow{2}{*}{$\begin{array}{l}\text { CV } \\
(\%)\end{array}$} & \multirow[t]{2}{*}{ DS } \\
\hline & 0 & 15 & 30 & & \\
\hline arcass conformation & 3.07 & 3.10 & 2.85 & 17.90 & 1.1790 \\
\hline Fat cover score & $2.72 \mathrm{ab}$ & $2.85 \mathrm{a}$ & $2.46 \mathrm{~b}$ & 16.74 & 1.1784 \\
\hline Fat color & $1.50 \mathrm{a}$ & $1.50 \mathrm{a}$ & $1.60 \mathrm{~b}$ & 8.47 & 1.1749 \\
\hline Fat consistency & 1.79 & 1.80 & 1.79 & 13.56 & 1.1771 \\
\hline Meat color & 1.64 & 1.75 & 1.80 & 15.05 & 1.1777 \\
\hline
\end{tabular}

CV - Coefficient of variation; DS - Deviance scaled.

a,b,c Means followed by different letters are statistically different by generalized parametric contrasts $(\mathrm{P}<0.06)$, having no effect at $(\mathrm{P}>0.05)$.

Carcass conformation (1 - inferior; 2 - regular; 3 - good; 4 - very good;

5 - excellent, dots); fat score (1 - absent; 2 - scarce; 3 - medium; 4 - uniform; 5 - excessive, dots); fat color (1 - white; 2 - yellowish; 3 - yellow, dots); Fat consistency (1 - firm to 3 - soft, dots); meat color (1 - pink; 2 - red; 3 - purple, dots).

proportions of volatile fatty acids generated by the fermentation of glycerin in the rumen (Kristensen \& Raun, 2007; Südekum, 2008). The fat color of 1.50 to 1.60 points, equivalent to a white color fat and consistency of 1.79 to 1.80 points, characteristic of a firm fat, were similar to those reported by Macedo et al. (2000): of 1.94 points for the color and 1.83 points for the consistency.

The meat color was pink, varying from 1.64 to 1.80 points, which was also reported by Reis et al. (2001): 1.56 points, indicating that in this study glycerin levels did not alter the color of the meat. Neither Gunn et al. (2010a), when studying the effect of 0 to $45 \%$ crude glycerin in sheep diet, nor Gunn et al.(2010b), when working with confined wethers and 0 to $20 \%$ glycerin, found any effect of up to 20 or even $30 \%$ of glycerin of total diet on carcass conformation, fat cover score, fat color, fat consistency or meat color, although they did find negative results using $45 \%$ glycerin. However, when considering a lower fat cover score $(\mathrm{P}<0.06)$, it might be possible to relate it to a lower production of acetate and higher production of propionate by animals receiving $30 \%$ glycerin (Abo El-Nor, 2010).

There was no effect $(\mathrm{P}>0.05)$ of treatments on weight and percentage of carcass commercial cuts (Table 5).

The average percentage (33.56\%) observed for the leg yield was similar to that found by Oliveira et al. (2002), who, working with Santa Inês lambs with an average slaughter weight of $30 \mathrm{~kg}$, reported a yield inferior to that found in this study $(32.75 \%)$.

Leg weight yields were also superior to those of Garcia et al. (2003), in a study related to the varying energy levels in finishing Suffolk lambs on creep feeding slaughtered at an average weight of $30 \mathrm{~kg}$, whose leg weight results were $2.57 \mathrm{~kg}$.

Loin yield averages were similar to those observed by Siqueira \& Fernandes (1999), 10.2\% in weaned finishing feedlot Corriedale lambs and crossbred (Ile de France $\times$
Table 5 - Carcass commercial cuts of confined Santa Inês lambs fed on diets with, or without, glycerin, and slaughtered with an average liveweight of 34 to $36 \mathrm{~kg}$

\begin{tabular}{|c|c|c|c|c|}
\hline \multirow[t]{2}{*}{ Variable } & \multicolumn{3}{|c|}{ Glycerin level (\%) } & \multirow{2}{*}{$\begin{array}{l}\text { CV } \\
(\%)\end{array}$} \\
\hline & 0 & 15 & 30 & \\
\hline Weigh of half carcass $(\mathrm{kg})$ & 7.95 & 8.01 & 7.94 & 5.3 \\
\hline Prime cuts $(\mathrm{kg} / \%)$ & 43.95 & 43.82 & 43.21 & 3.8 \\
\hline Leg weight (kg) & 2.69 & 2.65 & 2.67 & 6.0 \\
\hline Leg yield (\%) & 33.94 & 33.16 & 33.59 & 3.6 \\
\hline Loin weight (kg) & 0.80 & 0.86 & 0.76 & 11.8 \\
\hline Loin yield $(\%)$ & 10.01 & 10.66 & 9.62 & 10.7 \\
\hline Choice cuts $(\mathrm{kg} / \%)$ & 26.93 & 26.50 & 26.43 & 4.7 \\
\hline Shoulder weight (kg) & 1.46 & 1.47 & 1.45 & 6.2 \\
\hline Shoulder yield (\%) & 18.41 & 18.35 & 18.20 & 5. \\
\hline Rib weight (kg) & 0.68 & 0.65 & 0.65 & 11.8 \\
\hline Rib yield (\%) & 8.52 & 8.15 & 8.23 & 9.8 \\
\hline Good cuts $(\mathrm{kg} / \%)$ & 32.70 & 29.34 & 31.06 & 18.1 \\
\hline Trimmed rib weight $(\mathrm{kg})$ & 0.89 & 0.87 & 0.96 & 15.0 \\
\hline d rib yield $(\%)$ & 11.17 & 10.77 & 12.08 & 11.8 \\
\hline Breast and rib points weight $(\mathrm{kg})$ & 1.04 & 0.98 & 0.94 & 20.3 \\
\hline Breast and rib points yield $(\%)$ & 13.20 & 12.19 & 11.82 & 20.5 \\
\hline Neck weight $(\mathrm{kg})^{*}$ & 0.66 & 0.51 & 0.57 & 40.5 \\
\hline Neck yield (\%) & 8.33 & 6.38 & 7.16 & 40.8 \\
\hline
\end{tabular}

Treatment means have no statistically significant difference among themselves (Tukey's test $\mathrm{P}>0.05$ ).

${ }^{*}$ Analyzed based on the square root.

$\mathrm{CV}$ - Coefficient of variation.

Corriedale) lambs. Loin weight was, on average, superior to that obtained by Garcia et al. (2003), which was $0.78 \mathrm{~kg}$.

Shoulder yield indicated values lower than those reported by Zundt et al. (2006), with an average of 19.40\% for Santa Inês lambs. The shoulder weight was superior those observed by Garcia et al. (2003), who found $1.16 \mathrm{~kg}$.

Rib yield was similar to that acquired by Zundt et al. (2006), with Santa Inês lambs (8.27\%), and average rib weight $(0.66 \mathrm{~kg})$ was superior to that obtained by Garcia et al. (2003), of $0.37 \mathrm{~kg}$.

Low breast and rib points yield of $13.20 ; 12.19 ; 11.82 \%$ for control group and groups with $15 \%$ glycerin and $30 \%$ glycerin observed in this study was similar to that achieved by Siqueira \& Fernandes (1999), who obtained $12.3 \%$ in Corriedale lambs and crossbred (Ile de France $\times$ Corriedale) lambs.

Neck yield obtained by Zundt et al. (2006), in Santa Inês lambs was $6.07 \%$, a value inferior to the means obtained in this study (6.38 to $8.33 \%$ ), yet similar to the percentage (8\%) found by Siqueira \& Fernandes (1999).

Lage et al. (2009) found no effect on weight when studying confined Santa Inês lambs, as they reported weights of $0.69 ; 0.76 ; 0.62 ; 0.74$ and 0.58 when $0 ; 3 ; 6 ; 9$ and $12 \%$ of crude glycerin was added to the diet, respectively.

For the measurements of the longest and shortest sections of the loin and thickest and thinnest parts of the fat from the Longissimus dorsi muscle of Santa Inês lambs, no differences were observed $(\mathrm{P}>0.05)$ (Table 6). 
Table 6 - Loin measurements and thickness of confined Santa Inês lambs fed rations with or without glycerin

\begin{tabular}{lcccr}
\hline Variable & \multicolumn{3}{c}{ Glycerin level $(\%)$} & CV \\
\cline { 2 - 4 } & 0 & 15 & 30 & \\
\hline Loin eye area $\left(\mathrm{cm}^{2}\right)^{*}$ & 15.18 & 15.61 & 15.66 & 14.39 \\
Longer loin length $(\mathrm{mm}) *$ & 59.31 & 56.14 & 55.77 & 7.76 \\
Shorter loin length $(\mathrm{mm})$ & 28.62 & 29.91 & 29.97 & 13.87 \\
Thicker fat part (mm)* & 1.35 & 1.56 & 1.40 & 18.55 \\
Thinner fat part (mm)* & 1.04 & 1.09 & 1.03 & 21.76 \\
\hline Treatment means have no statistically significant difference (Tukey's test P>0.05). \\
* Analyzed based on the square root. \\
CV - Coefficient of variation.
\end{tabular}

The average measurements of the loin length (Table 6) were similar to the $54.9 \mathrm{~mm}$ of longer loin length obtained by Almeida et al. (2004), in Suffolk lambs, slaughtered with an average weight of $28 \mathrm{~kg}$, and with $26.82 \mathrm{~mm}$ of shorter loin length, but superior to those found by Siqueira \& Fernandes (2000), in Corriedale lambs, slaughtered with $32 \mathrm{~kg}$, and registering $51.00 \mathrm{~mm}$ for the longest loin length and $24.00 \mathrm{~mm}$ for shortest loin length.

Gunn et al. (2010a; 2010b), when feeding sheep with 0 to $45 \%$ or 0 to $20 \%$ glycerin in the diet, respectively, did not find any effect of glycerin on loin eye area, having reported the values of 17.2 to $20.5 \mathrm{~cm}^{2}$. In this study, the longest and shortest loin lengths were superior to those found by Garcia et al. (2003), who worked with crossbreed lambs slaughtered at $31 \mathrm{~kg}$, and observed $53.2 \mathrm{~mm}$ for longest loin length and $28.6 \mathrm{~mm}$ for shortest loin length.

In sheep, Gunn et al. (2010a) observed $0.65 ; 0.66 ; 0.38$ and $0.33 \mathrm{~cm}$ fat thickness on the $12^{\text {th }} \mathrm{rib}$, when using control, 15,30 and $45 \%$ glycerin diets, with a reduction starting at the $30 \%$ range. Gunn et al. (2010b), studying the effects of control, $5,10,15$ or $20 \%$ glycerin diets, obtained $0.51 ; 0.51 ; 0.55 ; 0.52$ and $0.53 \mathrm{~cm}$ of fat thickness on the $12^{\text {th }}$ rib, without any divergence, which is partly in agreement with the results obtained in this study.

There was no dietary effect $(\mathrm{P}>0.05)$ for the chemical composition of sheep meat (Table 7).

Meat humidity means were similar to those observed by Zeola et al. (2004), who obtained, in natura meat, 75.75\%

Table 7 - Meat physical-chemical composition of confined Santa Inês lambs fed, with or without glycerin

\begin{tabular}{|c|c|c|c|c|}
\hline \multirow[t]{2}{*}{ Variable } & \multicolumn{3}{|c|}{ Glycerin level (\%) } & \multirow{2}{*}{$\begin{array}{l}\text { CV } \\
(\%)\end{array}$} \\
\hline & 0 & 15 & 30 & \\
\hline Humidity (\%) & 75.49 & 75.34 & 74.97 & 1.46 \\
\hline Ash $(\%)$ & 1.04 & 1.07 & 1.04 & 4.10 \\
\hline Crude protein $(\%)$ & 21.62 & 22.53 & 22.73 & 5.12 \\
\hline Total fat $(\%)$ & 1.94 & 1.70 & 1.92 & 26.25 \\
\hline Shear force $(\mathrm{kg}) *$ & 5.07 & 5.10 & 5.27 & 42.29 \\
\hline Cooking losses $(\%)$ & 40.45 & 40.81 & 39.04 & 7.53 \\
\hline
\end{tabular}

humidity, working with confined lambs fed with a diet containing $60 \%$ concentrate and $40 \%$ forage.

Ash values of in natura meat were close to those found by Prata (1999), of 1.1\% and Souza et al. (2002), 1.17\%, observed for lambs slaughtered between 15 and $45 \mathrm{~kg}$.

Crude protein levels were considered high, when compared with those found by Ortiz et al. (2005), 19.66\%. Nevertheless, the results of Ortiz et al. (2005) concerned with the total fat value of $2.52 \%$ remain higher than those found in this study, which varied from 1.70 to $1.92 \%$. This effect might have occurred due to possible changes related to the proportion of volatile fatty acids, which may possibly alter fat deposition on the carcass and possibly the meat fatty acid profile (Abo El-Nor, 2010). According to Smith \& Crouse (1994), in research done with Angus bovines, the glucose originated from the propionic acid is responsible for up to $10 \%$ of the acetyl units in the subcutaneous fat tissue, and 50 to $75 \%$ of the intramuscular fat tissue. This may suggest, in the present study, that diets containing glycerin did not increase the proportion of propionate in the rumen, as Kristensen \& Raun (2007).

The results for meat tenderness varied from 5.07 to $5.27 \mathrm{~kg}$. Knapp et al. (1989) reported that a shear force over $4.5 \mathrm{~kg}$ in bovine meat makes it tough; below that value it is considered soft, when measured in the Longissimus dorsi, which can be considered a tough meat for this study. The values observed for this study were high, when compared with the $3.35 \mathrm{~kg}$ obtained in a study by Monteiro (1998) and to the $4.35 \mathrm{~kg}$ observed by Zeola (2002). However, there was no effect of glycerin diets on the shear force.

Cooking losses varied between 39.04 and $40.81 \%$ and were considered high when compared to the data found in the experiments of Neres et al. (2001), in which the loss was $17.78 \%$. Mourot et al. (1994) reported that diet glycerin can retain water in the muscle of swine, which, consequently, reduced carcass dripping during cooling and cooking losses. However, in this study a reduction in cooling losses was observed, but there was no reduction in cooking losses. Possibly, this is due to the differences in the digestive physiology of swine and sheep. Pethick et al. (2000) observed that a mixture of $3.5 \%$ glycerol and $1.5 \%$ propylene glycol doubled water ingestion in lambs. However, it was also reported that keeping lambs on glycerol diets improves meat quality due to the reduction of muscular glycogen loss.

\section{Conclusions}

Glycerin can be used in the diet of finishing lambs in values of up to $30 \%$ dry matter without causing any harmful effects on intake, performance or carcass characteristics of 
confined lambs. Therefore, glycerin is effective in partially substituting corn in the diets of feedlot lambs.

\section{Acknowledgments}

The authors gratefully acknowledge the assistance of Pedro Luiz de Castro and Thiago Carminati, Animal Science undergraduate students at UEM, for their contributions to this research.

\section{References}

ABO EL-NORB, S.; ABUGHAZALEHA, A.A.; POTUA, R.B. et al. Effects of differing levels of glycerol on rumen fermentation and Bacteria. Animal Feed Science and Technology, v.162, p. 99-105, 2010.

ALMEIDA JUNiOR, G.A.; COSTA, C.; MONTEIRO, A.L.G. Qualidade da carne de cordeiros criados em creep feeding com silagem de grãos úmidos de milho. Revista Brasileira de Zootecnia, v.33, n.4, p.1039-1047, 2004

BINES, J.A.; HART, I.C. The response of plasma insulin and others hormones to intraruminal infusion of VFA mixtures in cattle. Canadian Journal of Animal Science, v.64, p.304, 1984.

CHUNG, Y.H.; RICO D.E.; MARTINEZ C.M. et al. Effects of feeding dry glycerin to early postpartum Holstein dairy cows on lactational performance and metabolic profiles. Journal of Dairy Science, v.90, p.5682-5691, 2007.

DEFRAIN, J.M.; HIPPEN, A.R.; KALSCHEUR, K.F. et al. Feeding glycerol to transition dairy cows: Effects on blood metabolites and lactation performance. Journal of Dairy Science, v.87, p.4195-4206, 2004

DONKIN, S.S.; DOANE, P. Glycerol as a feed ingredient in dairy rations. In: TRI-STATE DAIRY NUTRITION CONFERENCE, 10., 2007, Ft. Wayne. Proceedings... The Ohio State University, Michigan State University, Purdue University, 2007. p.97-103.

GARCIA, C.A.; COSTA, C.; MONTEIRO, A.L.G. Níveis de energia no desempenho e característica da carcaça de cordeiros alimentados em creep feeding. Revista Brasileira de Zootecnia, v.32, n.6, p.1371-1379, 2003

GARCIA, I.F.F.; PEREZ, J.R.O.; TEIXEIRA, C.J. Desempenho de cordeiros Texel x Santa Inês puro, terminados em confinamentos, aleitamentos com casca de café como parte da dieta. Revista Brasileira de Zootecnia, v.29, n.2, p. 564-572, 2000.

GUNN, P.J.; SCHULTZ, A.F.; VAN EMON, M.L. et al. Effects of elevated crude glycerin concentrations on feedlot performance, carcass characteristics, and serum metabolite and hormone concentrations in finishing ewe and wether lambs. The Professional Animal Scientist, v.26, p.298-306, 2010a.

GUNN, P.J.; NEARY, M.K.; LEMENAGER, R.P. et al. Effects of crude glycerin on performance and carcass characteristics of finishing wether lambs. Journal of Animal Science, v.88, p.1771-1776, 2010b.

THE INTERNATIONAL UNION OF PURE AND APPLIED CHEMISTRY - IUPAC. [1997] Compendium of Chemicalterminology. Available at $:<$ http://www.iupac.org/publications/compendium/ index.html.>. Accessed on: Mar. 15, 2007.

KIJORA, C.; BERGNER, H.; KUPSCH, R.D. et al. Glycerol as a feed component in diets of fattening pigs. Archiv fur Tierernahrung, v.47, p. 345-60, 1995.

KNAPP, R.H.; TERRY, C.A; SAVELL, J.W. et al. Charcacterization of cattle types to meet specific beef targets. Journal of Animal Science, v.67, p.2294-2308, 1989.

KRISTENSEN, N.B.; RAUN B.M.L. Ruminal fermentation, portal absorption, and hepatic metabolism of glycerol infused into the rumen of lactating dairy cows. In: INTERNATIONAL
SYMPOSIUM ON ENERGY AND PROTEIN METABOLISM AND NUTRITION, 2., 2007, Ortigues- Marty, Proceedings... Marty: EAAP Publication, Wageningen Academic Publishers, 2007. p.355-356.

LAGE, J.F.; PAULINO, P.V.R.; PEREIRA, L.G.R. et al. Glicerina bruta na dieta de cordeiros terminados em confinamento. Pesquisa Agropecuária Brasileira, v.45, p.1012-1020, 2010

LAGE, J.F.; PAULINO, P.V.R.; PEREIRA, L.G.R. et al. Glicerina bruta na dieta de cordeiros em confinamento e seus efeitos sobre o peso e rendimento de cortes comerciais da carcaça. In: ZOOTEC 2009, 2009, Águas de Lindóia. Anais... FZEA/USP, Associação Brasileira de Zootecnia, 2009. (CD-ROM).

LEBZIEN, P.; AULRICH, K. Zum Einfluss von Glycerin auf die Rohnährstoff verdaulichkeit und einige Pansenparameter bei Milchkühen. VDLUFÄ-Schriftenreihe, v.37, p.361-364, 1993.

MACEDO, F.A.F.; SIQUEIRA, E.R.; MARTINS, E.N. et al Qualidade de carcaças de cordeiros Corriedale, Bergamácea $\mathrm{x}$ Corriedale e Hampshire Down x Corriedale, terminados em pastagem e Confinamento. Revista Brasileira de Zootecnia, v. 29, n. 5 , p. $1520-1527,2000$.

MACEDO, F.A.F.; SIQUEIRA, E.R.; MARTINS, E.L. et al. Características quantitativas das carcaças de cordeiros Corriedale, Bergamácea-Corriedale e Hampshire DownCorriedale, terminados em pastagem ou em confinamento. Acta Science Animal Science, v.28, n.3, p.339-344, 2006.

MACH, N.; BACH, A.; VELARDE A., et al. Association between animal, transportation, slaughterhouse practices, and meat $\mathrm{pH}$ in beef. Meat Science, v.78, p.232-238, 2008.

MONTEIRO, E.M. Influência do cruzamento Ile de France $\mathbf{x}$ Corriedale (F1) nos parâmetros de qualidade da carne de cordeiro. 1998. 99f. Tese (Doutorado em Ciência dos Alimentos) - Faculdade de Ciências Farmacêuticas, Universidade de São Paulo, São Paulo.

MOUROT, J. ; AUMAitRe, A.; MOUNIER, A. et al. Nutritional and physiological effects of dietary glycerol in the growing pig. Consequences on fatty tissues and post mortem muscular parameters. Livestock Production Science, v.38, p.237-244, 1994.

MUSSELMAN, A.F.; VAN EMON, M.L.; GUNN, P.J. et al. Effects of crude glycerin on feedlot performance and carcass characteristics of market lambs. In: WESTERN SECTION, AMERICAN SOCIETY OF ANIMAL SCIENCES, 2008, West Lafayette. Proceedings... Purdue University Department of Youth Development and Agricultural Education and Department of Animal Sciences, 2008. p.353-355.

NATIONAL RESEARCH COUNCIL - NRC. Nutrient requirements of small ruminants: sheep, goats, cervids and new world camelids. Washington: The National Academies Press, 2007. $384 \mathrm{p}$.

NERES, M.A.; MONTEIRO, A.L.G.; GARCIA, C.A. et al. Forma física da ração e pesos de abate nas características de carcaça de cordeiros em creep feeding. Revista Brasileira de Zootecnia, v.30, n.3, p.948-954, 2001.

NIELSEN, N.I.; INGVARTSEN K.L. Propylene glycol for dairy cows: A review of the metabolism of propylene glycol and its effects on physiological parameters, feed intake, milk production and risk of ketosis. Animal Feed Science Technology, v.115, p.191-213, 2004.

OLIVEIRA, M.V.M.; PÉRES, J.R.O.; ALVES, E.L. Avaliação da composição de cortes comerciais componentes corporais e órgãos internos de cordeiros confinados e alimentados com dejetos de suínos. Revista Brasileira de Zootecnia, v.31, n.3, p.1459-1468, 2002 .

ORTIZ, J.S.; COSTA, C.; GARCIA, C.A. et al. Efeito de diferentes níveis de proteína bruta na ração sobre o desempenho e as características de carcaça de cordeiros terminados em creep feeding. Revista Brasileira de Zootecnia, v.34, p.2390-2398, 2005.

OSÓRIO, J.C.S. Qualidade, morfologia e avaliação de carcaças. Pelotas: UFPEL, 2002. 197p. 
PARSONS, G.L.; SHELOR, M.K.; DROUILLARD, J.S. Performance and carcass traits of finishing heifers fed crude glycerin. Journal of Animal Science, v.87, p.653-657, 2009.

PETHICK, D.W.; CUMMINS, L.; GARDNER, G.E. et al. The regulation of glycogen level in the muscle of ruminants by nutrition. New Zealand: New Zealand Society of Animal Production, v.60, 2000. p.94-98.

PRATA, L.F. Higiene e inspeção de carnes, pescado e derivados. Jaboticabal: FUNEP, 1999. 217p.

PYATT, A.; DOANE, P.H.; CECAVA, M.J. Effect of crude glycerin in finishing cattle diets. Journal of Animal Science, v. 85 (supplement 1), p.412, 2007.

REIS, W.; JOBIM, C.C.; MACEDO, F.A.F. Desempenho de cordeiros terminados em confinamento, consumindo silagens de milho de grãos com alta umidade ou grãos de milho hidratados em substituição aos grãos de milho seco da dieta. Revista Brasileira de Zootecnia, v.30, n.2, p.596-603, 2001.

STATISTICAL ANALYSES SYSTEM - SAS. Statistics analysis system. Release 9.1.3. Cary: SAS Institute Inc., version, 1999-2001.

SILVA, D.J.; QUEIRROZ, A.C. Análise de alimentos: métodos químicos e biológicos. 3.ed. Viçosa, MG: Universidade Federal de Viçosa, 2002. 235p.

SIQUEIRA, E.R.; FERNANDES, S. Pesos, rendimentos e perdas da carcaça de cordeiros Corriedale e mestiços Ile de France $\mathrm{x}$ Corriedale, terminados em confinamento. Ciência Rural, v.29, n.1, p.143-148, 1999.

SIQUEIRA, E.R.; FERNANDES, S. Efeito do genótipo sobre as medidas objetivas e subjetivas da carcaça de cordeiros terminados em confinamento. Revista Brasileira de Zootecnia, v.29, n.1, p.306-311, 2000.

SIQUEIRA, E.R.; SIMÕES, C.D.; FERNANDES, S. Efeito do sexo do peso ao abate sobre a produção de carne de cordeiro. I. Velocidade de crescimento, caracteres quantitativos da carcaça, $\mathrm{pH}$ da carne e resultado econômico. Revista Brasileira de Zootecnia, v.30, n.3, p.844-848, 2001.

SMITH, S.B.; CROUSE, J.D. Relative contributions of acetate, lactate and glucose to lipogenesis in bovine intramuscular and subcutaneous adipose tissue. Journal of Nutrition, v.114, p.792-800, 1994.

SOUZA, X.R.; PEREZ, J.R.; O BRESSAN, M.C. et al. Composição centesimal do músculo Biceps femoris de cordeiros em crescimento. Revista Ciência Agrotécnica, p.1507-1513, 2002.

SCHRÖDER, A.; SÜDEKUM K-H. Glycerol as a by-product of biodiesel production in diets for ruminants. Kiel, Germany: University of Kiel: Institute of Animal Nutrition, Physiology and Metabolism. Available on: <http://regional.org.au/ $\mathrm{au} / \mathrm{gcirc} / 1 / 241 . \mathrm{htm}>$ Accessed on: Jul. 23, 2007.

SÜDEKUM, K-H. Co-products from biodiesel production. In: GARNSWORTHY, P.C.; WISEMAN, J. (Eds.). Recent advances in animal nutrition. Nottingham: Nottingham University Press, 2008. p.210-219.

THOMPSON, J.C.; HE, B.B. Characterization of crude glycerol from biodiesel production from multiple feedstocks. Applied Engineering Agriculture,v.22, n.2, p.261-265, 2006.

WHEELER, T.L.; SHACKELFORD, S.D.; KOOHMARAIE, M. et al. Beef longissimus slice shear force measurement among steak locations and institutions. Journal of Animal Science, v. 85 , p. 2283-2289, 2007.

YAMAMOTO, S.M.; MACEDO, F.A.F.; ZUNDT, Z. Fontes de óleo vegetal na dieta de cordeiros em confinamento. Revista Brasileira de Zootecnia, v.34, n.2, p.703-710, 2005.

ZEOLA, N.M.B.L.; SILVA SOBRINHO, A.G.; GONZAGA NETO, S. et al. Composição centesimal da carne de cordeiros submetidos a dietas com diferentes teores de concentrado. Ciência Rural, v.34, n.1, p.253-257, 2004

ZEOLA, N.M.B.L.; SILVA SOBRINHO, A.G.; GONZAGA NETO, S et al. Influência de diferentes níveis de concentrado sobre a qualidade da carne de cordeiros Morada Nova. Revista Portuguesa de Ciências Veterinárias, v.97, n.544, p.175-180, 2002.

ZUNDT, M.; MACEDO, F.A.F.; ASTOLPHI, J.L.L. et al. Desempenho e características de carcaça de cordeiros Santa Inês confinados, filhos de ovelhas submetidas à suplementação alimentar durante a gestação. Revista Brasileira de Zootecnia, v.35, n.3, p.928-935, 2006 